\title{
GCU
}

Glasgow Caledonian

University

University for the Common Good

\section{Two paths of social innovation in the post-pandemic world}

Montgomery, Thomas; Mazzei, Micaela

Published in:

Social Enterprise Journal

DOI:

10.1108/SEJ-03-2021-0018

Publication date:

2021

Document Version

Author accepted manuscript

Link to publication in ResearchOnline

Citation for published version (Harvard):

Montgomery, T \& Mazzei, M 2021, 'Two paths of social innovation in the post-pandemic world', Social Enterprise Journal, vol. 17, no. 3, pp. 450-458. https://doi.org/10.1108/SEJ-03-2021-0018

\section{General rights}

Copyright and moral rights for the publications made accessible in the public portal are retained by the authors and/or other copyright owners and it is a condition of accessing publications that users recognise and abide by the legal requirements associated with these rights.

Take down policy

If you believe that this document breaches copyright please view our takedown policy at https://edshare.gcu.ac.uk/id/eprint/5179 for details of how to contact us. 


\title{
Two paths of social innovation in the post-pandemic world
}

\author{
Tom Montgomery and Micaela Mazzei \\ Yunus Centre for Social Business and Health \\ Glasgow Caledonian University \\ George Moore Building \\ Cowcaddens Road \\ Glasgow, G4 0BA
}

\begin{abstract}
- Purpose - The Covid-19 pandemic has initiated a period of radical uncertainty, resulting in impacts on a scale that has and will continue to transform economies and societies across various contexts. Social innovation resonates with the challenges the pandemic presents. In this paper we seek to address the question of which form of social innovation will be most pivotal in the post-pandemic world.

- Design/methodology/approach - The paper has been developed by reviewing key literature on social innovation, with a specific focus on the most current contributions of Moulaert and MacCallum and Mulgan.

- Findings - SI is embedded in debates around social change but the 'type' of social change that dominates the future of SI is connected to how SI interacts at different scales and with different actors engaged in shaping change in specific contexts. Building upon extant knowledge of social innovation we can hypothesise two paths of social innovation emerging/intensifying: one that seeks economic reform with an emphasis on meeting social needs in new ways and another that seeks complete systemic change.

- Originality - This is a reflective piece that by reviewing current contributions to the social innovation literature questions the post-pandemic future of the field.
\end{abstract}

Keywords: post-pandemic recovery, social innovation, future pathways 


\section{Why social innovation may matter more than ever - post-pandemic recovery}

COVID-19 has governments operating in a context of radical uncertainty, and faced with difficult trade-offs given the health, economic and social challenges it raises. The pandemic has resulted in impacts on a scale that has and will continue to transform the economy and society across various contexts.

Alongside the health crisis and human tragedy of the Coronavirus, it is now widely recognised that the pandemic has triggered one of the most serious economic crisis in a century. The OECD predicted global economic activity to fall between 6\% and 7.6\% in 2020 (OECD, 2020). While this is a period of tumult, specific implications are already evident across areas of public health (e.g. pressure on primary care but also social care and the social determinants of health); local / global economies (e.g. sector disruption, impact on global supply chains) and public budgets (e.g. greater health and welfare expenditure and the need to raise tax revenue).

Against a background that threatens to widen inequalities (Marmot and Allen, 2020) it is therefore ever more pressing to develop initiatives which tackle inequality and social exclusion, and which aim to empower marginalised groups in their social and economic lives. It is in this context that we turn our attention to those innovative practices that citizens undertake to meet their needs, when institutions of the state and the market fall short of meeting the requirements of the population, but particularly those sections of the population at acute risk of further marginalisation.

The term 'social innovation' has been increasingly mobilised by scholars despite the contestation over its meaning (Pol and Ville, 2009; Montgomery, 2016; Ayob et al, 2016). The contemporaneous debates encompass conceptual discussions as well as argumentations around the development of new forms of economic organising (Gibson-Graham, 2008; Ridley-Duff and Bull 2011; Spear et al, 2018). Despite the growth in literature on social innovation in recent years, it is important to not overlook the historicity of the subject. Social innovations of one sort or another have long been an avenue of inquiry for social science research stretching back as far as classical sociologists such as Durkheim and Weber investigating the complex societal transformations, (new institutional frameworks, forms of control and solidarity) which accompanied the techno-economic innovations of the 19th century (Moulaert 2009). Thus social innovation practices are embedded within those periods of economic and societal upheaval and forms something of a nexus for understanding responses to periods of radical uncertainty about the future (Moulaert and Ailenei, 2005). Drawing upon extant knowledge of 
social innovation, this reflective piece questions the post-pandemic future and hypothesises two paths of social innovation emerging and/or intensifying: one that seeks economic reform with an emphasis on meeting social needs in new ways and another that seeks complete systemic change.

\section{A decisive moment for social innovation in both research and practice}

The Covid-19 pandemic has significant consequences for health inequalities (Bambra et al, 2020), and wider societal inequalities (Sumner et al, 2020; Guadagno, 2020; Collins et al, 2021) and at the same time, precipitated (or perhaps accelerated) discussions about how policy measures and civil society responses may speak to visions of an alternative future. The pandemic has not only had a societal impact (particularly in terms of reshaping our social relations through 'lockdowns' and 'social distancing') but has also contributed towards transforming our economy with changes in consumer behaviour, the intensification of the online economy, the demise of some sectors and sub-sectors and the acceleration of change in the labour market (van Barneveld et al, 2020). However, rather than view the pandemic as being a shift from one economic epoch to another, it is, we argue, best to perceive its impact as being an accelerant of processes that were already in motion such as the growing concentration of digital monopolies (Srnicek, 2017).

Against this background, the future of social innovation is also at stake. It will be determined not only by the types of organisations that survive and emerge to respond to growing needs, but also the relationships between these organisations and other societal actors (De Pieri and Teasdale 2021, Bozic, 2020), particularly policymakers at different scales of governance: local, regional, national and transnational. These relationships may become characterised by consensus, compromise or even conflict and much will of course depend on the shared vision (or lack thereof) of a post-pandemic future. Given that the pandemic is a transnational event and even though the impact will map onto different contexts in different ways, the global nature of its effect means that this is a decisive moment for thinking about new approaches for meeting social and economic challenges. It is within this specific milieu that the future of social innovation will be determined.

Social innovation, which involves the meeting of human needs and transforming social relations, clearly resonates with the challenges the pandemic presents. It is also often mobilised in periods of crisis and the organisations which are so often associated with social innovation 
can often become more visible as potential 'alternatives' for meeting human needs when the market or the state has come under pressure or even failed. However, although social innovation will undoubtedly have a role to play in the recovery from the pandemic, we are left with the question: which interpretation of social innovation will truly shape the post-pandemic world? The contestation over social innovation reflects different relations to the market economy, with some seeking to implement reform and others aiming for a departure from market logic towards systemic change. Therefore, through an understanding of the existing literature on social innovation, not only in theory but also on empirical studies conducted across various contexts, we can hypothesise that two paths of social innovation will emerge (or more precisely intensify given the existing division within social innovation). One that seeks market reform with an emphasis on meeting social needs in new ways and another that seeks systemic change.

In the recent literature on social innovation these different paths to alternative futures have been encapsulated by the works of key theorists in the field of social innovation. On the one hand that of Mulgan (2019) and on the other hand Moulaert and MacCallum (2019). Their most recent works provide further evidence and argumentations around the topic of social innovation but from two very distinct perspectives.

\section{Social Innovation as a solution to global social challenges through research, technology and science: Mulgan}

There have been a multitude of contributions from across the globe to advance our understanding of social innovation. However, some theorists have been something of a permanent fixture in those debates concerning the development of social innovation (Murray et al, 2010). One such thinker, is Geoff Mulgan, an advocate of social innovation who has argued that societal challenges offer new opportunities for reforming processes of economic growth (Mulgan, 2007). In his most recent work (Mulgan, 2019), while acknowledging that social innovation occurs in all spheres of society (i.e. the private, public and civil society sectors), emphasis is placed upon examples of organisations in the private sector - particularly those associated with the digital economy, from Google to AirBnB - and the lessons that can be gleaned from their successes. Therefore, there is an understanding of social innovation that can be - and is - delivered in the framework of the market, and enables a space to be created for the market and for market logics to be infused into the realm of the social. 
Mulgan acknowledges some of the shortcomings of capitalism in its current disposition and seeks reform through sustainable entrepreneurship, drawing inspiration from the organisational processes of capitalism. Prominence is given to the individuality of innovators, including an appreciation of the Schumpeterian notion of individual change makers, while the potential of the collective is framed in terms of the support system for entrepreneurial activities (Mulgan 2019).

Recognising the challenges that social innovators face in implementing their ideas, Mulgan acknowledges the role played by the State in contributing to the development of a supportive environment for social innovation, through political recognition, provision of spaces for experimentation and tailored policies that promote cross-sector collaborations. This approach for state support to social innovation resonates with those arguments in favour of creating hubs for entrepreneurship in the private sector, which indicate a meshing of social and economic goals through a marketized frame. Mulgan (2019) indicates an awareness of the importance of context but only in broad terms, such as the pursuit of change at the sector or regional levels. Moreover, it becomes difficult to reconcile the connection between social innovation and political movements which he calls for with the mode of social innovation he outlines, that embraces the very logics and organisational processes that progressive movements may seek to challenge.

Throughout his analysis, Mulgan appears to somewhat relegate the contextual determinants of social innovation and the varying factors that contribute to the differing opportunities for Social Innovation to be effective in its transformative power. This is not so surprising when we consider the pathway towards social innovation that Mulgan illuminates, one that draws upon market forces that are often transnational in nature. This approach to social innovation carries with it a particular concern with scaling up. However, a consequence of doing so is to risk obscuring a more nuanced understanding of how markets and their logic, map on to different contexts differently (Brenner and Theodore, 2002). In turn, a less focused appreciation of the contextual socio-spatial dynamics also risks overlooking how social innovation practices are supported (or not) at different scales of governance. Later in this article we will look more closely at how such an appreciation of these dynamics in the case of the UK helps further our understanding of the different pathways of Social Innovation futures. 
Social Innovation as an ethical and socio-political agency for more inclusive societies: Moulaert and MacCallum

Recognising that Social Innovation is a contested concept, despite the increased attention from policymakers across a variety of contexts as a way to tackle societal challenges, and drawing on empirical evidence gathered through years of researching social innovation across a variety of contexts (geographical and sectorial), Moulaert and MacCallum (2019) focus on the role of the 'social' in solving political, economic and societal challenges at different scales. Moulaert and MacCallum emphasise a community focused meaning of social innovation, as locally grounded initiatives that promote inclusion and change societies for the better by meeting basic needs; creating new forms of social relations and collectively empowering communities.

While recognising that social innovation has economic dimensions, Moulaert and MacCallum steer away from market-oriented interpretations and instead move towards political/emancipatory projects and focus on concerns of participatory governance. These thinkers do however argue for a more nuanced, multidisciplinary reading of social innovation, emphasising that through dialogue our understanding of the phenomenon can be enhanced and scholarly and disciplinary silos should be averted, thus reflecting earlier endeavours for a transdisciplinary approach to Social Innovation (Moulaert et al, 2013).

Moulaert and MacCallum, building upon a long term engagement in this field of research have gathered substantial, empirically driven analysis on the centrality of the context and how the types of social, spatial and institutional dynamics present in specific places shape social innovation (Moulaert et al, 2007). Given the emphasis placed on the local dimension of social innovation ventures, it is unsurprising that the authors recognise the crucial role of the sociospatial forces that shape the context in which social innovation develops (Moulaert et al. 2013). The authors argue that the characteristics of each locality shape the nature of the human needs that are to be satisfied, the social relations and the socio-political forces that contribute to the transformative potential of social innovation. Social innovation can therefore be understood as a territorial phenomenon shaped by the history of the place, albeit not limited by it, and embedded in social relations and institutions that are conditioned by scalar dynamics (Mazzei and Montgomery, 2020). Moreover, the approach from Moulaert and MacCallum (2019) rejects those efforts to mobilise social innovation to be a cheaper alternative to state provision. Instead, it is perceived as collective action that adopts a highly contextualised approach. This brings together grassroots organisations and political actors in communities to jointly identify 
problems and co-create solutions that reverse the trend of neoliberalisation and help build counter-hegemonic knowledge as a long-term legacy of their projects.

\section{Looking to the future}

When we discuss the potential for social innovation in contributing towards the post pandemic recovery it once again highlights the importance of precision in terms of what we mean. In particular, as social innovators become more involved in the meeting of social needs during a period of crisis, they will often be well placed to identify gaps in provision especially for the most vulnerable groups. As a consequence, the specific demands that will emerge in terms of the interventions that are needed by the government will begin to offer some insight into the future direction of social innovation in a given context. Emerging evidence suggests that Covid-19 has exacerbated many pre-existing inequalities across many domains such as income, wealth, living standards, labour market participation, health, education and life chances(chances of achieving positive outcomes and avoiding negative outcomes throughout the course of your life) ${ }^{1}$. For example, evidence from the Office for National Statistics (2020) has revealed a stark social gradient in the mortality rates associated with Covid-19 and significant socio-geographic variation in death rates across local authorities in England and Wales. Similarly, in Scotland, geographic and socio-economic factors have been noted as potential reasons for the differential Covid-19 mortality rates experienced in some parts of the country (Public Health Scotland, 2020).

Understanding how these inequalities will shape communities in the future is of course connected to understanding how, why and where, social innovation may emerge to meet fundamental needs. When seeking to map the two potential futures of Social Innovation we can of course, through comparative studies, enhance our understanding of the differences between countries. However, another useful endeavour can be examining a specific political context to understand how two different paths may be pursued within the architecture of one state.

\section{A case in point: the $U K$}

\footnotetext{
${ }^{1}$ https://www.gov.scot/binaries/content/documents/govscot/publications/research-andanalysis/2020/09/the-impacts-of-covid-19-on-equality-in-scotland/documents/full-report/fullreport/govscot\%3Adocument/Covid\%2Band\%2BInequalities\%2BFinal\%2BReport\%2BFor\%2BPublication\%2B\%2BPDF.pdf
} 
In order to trace the paving of two paths to the future in Social Innovation, we turn to the UK context. This is a context that provides a key potential site of change in the social innovation landscape in terms of post-pandemic futures. Firstly, the decision by the UK electorate to vote to leave the European Union, means that one of the key policy venues for social innovation will no longer hold the same significance and/or relevance for key organisations and policymakers engaged in the field of social innovation in the UK. Secondly, there are political dynamics within the UK that suggest variegated environments for the development of social innovation. To understand this better, let's turn to the specific differences emergent in Scotland and England.

We can first recognise the differentiated contexts within the UK by appreciating approaches towards meeting basic needs that are being elaborated through the institutional architecture such as the Scottish and UK Government. In other words, we can recognise how cuts to welfare support for those groups and geographies experiencing inequalities have been pursued on the one hand at Westminster (O’Hara, 2015; Farnsworth, 2021) and somewhat resisted by the Scottish Government (Wiggan, 2017). Thus, we can begin to understand that these different environments of state support for meeting basic needs may help to shape landscapes of governance that social innovations may be nurtured within.

Of course, these divergences within the UK have also been reflected by extant research on the social economy. This is most frequently elaborated through an awareness of the efforts to distinguish on the one hand an environment in England where policy initiatives have contributed towards the development of a landscape where those ecologies of local actors have been enmeshed in market-oriented processes (Lowndes and Pratchett, 2012; Williams et al, 2014; Lowndes and Gardner, 2016). On the other hand, there is the environment in Scotland which has been identified as a milieu where sector representatives and some policymakers have sought to push back against the influence of market forces including upon those local organisations that are often engaged in socially innovative practices (McHugh et al, 2013; Hazenberg et al, 2016), exemplified to some extent by the widespread commitment to 'the Code'. Thus, broadly speaking, what we can elicit from a cursory examination of variation within a state such as the UK, is the importance of recognising how the political context may lend itself to one path of social innovation rather than another. However, this is but one layer of contextualisation. 
A more fine-grained approach is to recognise how those local contexts of governance (urban, peri-urban, rural) are also crucial for grounding social innovation practices in an awareness of how those larger scales of market and state dynamics have impacted upon community and neighbourhood level development. Doing so thus requires an approach to social innovation that is sensitive to these localised contexts and the capacity for community members not only to be involved in the development of solutions but also the identification of needs. For this reason, we conclude that those approaches which embrace a market ontology in a context where policy has been driven to withdraw support - as has been witnessed by UK Government policies on austerity - leads us down the path of one future of social innovation that may obscure the potential for socio-economic change. Instead, those approaches to social innovation which are focused on the socio-spatial dynamics that help to shape the identification of needs and solutions at community and neighbourhood levels offer a pathway to a different future that is geared towards transformative ends. At this point it is too early to say which pathways may become more dominant within the UK. However, we may hypothesise that in the context of policy discourses such as those in Scotland that eschew austerity from Westminster and where the social economy has as a sector been seen to push back against market forces then the opportunities for transformative social innovation to be nurtured in communities and neighbourhoods may be more apparent. Recognising this potential divergence needs not overlooking the risks and shortcomings that can be identified within the Scottish polity (see McKendrick et al, 2016; Mooney and Scott, 2016), but instead appreciating the differentiated opportunities in the English context (Hastings et al, 2017).

\section{One future, two paths?}

Depending on the adherence to different schools of thought, the path to the future understanding and applications of social innovation will vary significantly. On the one hand we have the vision developed by Mulgan that views a role for the market and for market logics to be adopted into the realm of the social. Embedded within Mulgan's analysis and suggestions on how to move beyond social innovation as a series of pilots and projects is the idea of sustainable entrepreneurship (Mulgan 2019). In this case we would expect the choice of initiatives to be studied would focus on technological initiatives, reflecting the relevance of technological innovations. These would discuss the broader picture of social innovation but would lack a contextual understanding of what would affect its potential. 
On the other hand, a substantial body of literature in territorial studies explores the potential of social innovation for the development of new forms of governance, community formation and participation (Moulaert et al. 2010). Sub-concepts such as milieu of innovation and social capital stress the depth and effectiveness of networking and collaboration for regional economic competitiveness (Fromhold-Eisebith 2004). Indeed, since its emergence as a prominent policy field, social innovation has been considered as a new phenomenon, generally linked to a renewed interest in the social economy, which policymakers often identify as vehicles for delivering welfare. However, from the outset of this work, Moulaert and MacCallum - while recognising that social innovation has economic dimensions - aim to steer our understanding away from those market-oriented interpretations and towards the political. In this case, we would expect the research focus to be on smaller solidarity groups, very localised and embedded in the processes of collective problematisation and co-creation. We can appreciate therefore how the distinction between two paths of conceptual juncture will deepen and while change will occur is yet to be determined who will shape it. 


\section{References}

Ayob, N., Teasdale, S., \& Fagan, K. (2016). How social innovation 'came to be’: Tracing the evolution of a contested concept. Journal of Social Policy, 45(4), 635-653.

Bambra, C., Riordan, R., Ford, J., \& Matthews, F. (2020). The COVID-19 pandemic and health inequalities. J Epidemiol Community Health, 74(11), 964-968.

Bozic, A. (2020), "Global trends in a fragile context: public-nonpublic collaboration, service delivery and social innovation", Social Enterprise Journal, https://doi.org/10.1108/SEJ-12-2019-0100

Brenner, N., \& Theodore, N. (2002). Cities and the geographies of “actually existing neoliberalism”. Antipode, 34(3), 349-379.

Collins, C., Landivar, L. C., Ruppanner, L., \& Scarborough, W. J. (2021). COVID-19 and the gender gap in work hours. Gender, Work \& Organization, 28, 101-112.

Dash, A., (2012). Social Innovations and the institutional challenge in microfinance. In: Franz, H.W., Hochgerner, J., and Howaldt, J., (eds.) Challenge social innovation, potentials for business, social entrepreneurship, welfare and civil society. Heidelberg: Springer.

De Pieri, B. and Teasdale, S. (2021), Radical futures? Exploring the policy relevance of social innovation, Social Enterprise Journal, 17(1), pp. 94-110

European Commission, (2010) This is European social innovation, Brussels.

Farmer, J. and Kilpatrick, S., (2009). Are rural health professionals also social entrepreneurs? Social science \& medicine, 69 (11), 1651 - 1658

Farnsworth, K. (2021). Retrenched, Reconfigured and Broken: The British Welfare State after a Decade of Austerity. Social Policy and Society, 20(1), 77-96.

Fromhold-Eisebith, M., (2004). Innovative milieu and social capital - complementary or redundant concepts of collaboration-based regional development? European Planning Studies, 12 (6).

Gibson-Graham, J. K. (2008). Diverse economies: performative practices forother worlds'. Progress in human geography, 32(5), 613-632. 
Guadagno, L. (2020). Migrants and the COVID-19 pandemic: An initial analysis. Geneva: International Organization for Migration.

Grimm, R., and Milestone, K., (2009). Manchester, Huddersfield: place, culture and urban change. In: van Boom, N., and Mommaas, H., (eds.) Transformation strategies for former industrial cities. Tilburg: NAi PublisherIacobucci, 2020.

Hastings, A., Bailey, N., Bramley, G., \& Gannon, M. (2017). Austerity urbanism in England: The ‘regressive redistribution' of local government services and the impact on the poor and marginalised. Environment and Planning A, 49(9), 2007-2024.

Hazenberg, R., Bajwa-Patel, M., Roy, M. J., Mazzei, M., \& Baglioni, S. (2016). A comparative overview of social enterprise 'ecosystems' in Scotland and England: An evolutionary perspective. International Review of Sociology, 26(2), 205-222.

Lowndes, V., \& Pratchett, L. (2012). Local governance under the coalition government: Austerity, localism and the 'Big Society'. Local government studies, 38(1), 21-40.

Lowndes, V., \& Gardner, A. (2016). Local governance under the conservatives: Superausterity, devolution and the 'smarter state'. Local government studies, 42(3), 357-375. Marmot, M., \& Allen, J. (2020). COVID-19: exposing and amplifying inequalities. $J$ Epidemiol Community Health, 74(9), 681-682.

Mazzei, M. and Montgomery, T. (2020). Advanced introduction to social innovation, Regional Studies, 54:11, 1627-1628.

McHugh, N., Sinclair, S., Roy, M., Huckfield, L., \& Donaldson, C. (2013). Social impact bonds: a wolf in sheep's clothing?. Journal of Poverty and Social Justice, 21(3), 247-257.

McKendrick, J. H., Asenova, D., MacRae, C., Reynolds, R., Egan, J., Hastings, A., \& Sinclair, S. (2016). Conceptualising austerity in Scotland as a risk shift: Ideas and implications. Scottish affairs, 25(4), 451-478.

Mooney, G., \& Scott, G. (2016) Welfare, equality and social justice: Scottish independence and the dominant imaginings of the 'New'Scotland. Ethics and Social Welfare, 10(3), 239-251.

Montgomery, T. (2016). Are social innovation paradigms incommensurable?. Voluntas: International Journal of Voluntary and Nonprofit Organizations, 27(4), 1979-2000. 
Moulaert, F., \& Ailenei, O. (2005). Social economy, third sector and solidarity relations: A conceptual synthesis from history to present. Urban studies, 42(11), 2037-2053.

Moulaert, F., Martinelli, F., Swyngedouw, E. and Gonzalez, S., (2005). Towards alternative model (s) of local innovation. Urban studies, 42(11), 1969-1990.

Moulaert, F., Martinelli, F., Gonzalez, S., \& Swyngedouw, E. (2007). Introduction: Social innovation and governance in European cities-Urban development between path dependency and radical innovation. European Urban and Regional Studies, 14(3), 195209.Moulaert, F., (2009). Social innovation: institutionally embedded, territorially. In: MacCallum, D., Moulaert, F., Hiller, K., and Haddock, V., (eds.) Social innovation and territorial development, Franaham: Ashgate Publishing Limited

Moulaert, F., MacCallum, D., Mehmood, A., \& Hamdouch, A. (2013). The international handbook on social innovation: Collective action, social learning and transdisciplinary research. Edward Elgar Publishing.

Moulaert, F., \& MacCallum, D. (2019). Advanced introduction to social innovation. Edward Elgar Publishing.

Mulgan, G., Tucker, S., Ali, R, and Sanders, B., (2007). Social innovation: what it is, why it matters and how it can be accelerated. Oxford: Said Business School.

Murray, R., Caulier-Grice, J., \& Mulgan, G. (2010). The open book of social innovation (Vol. 24). London: Nesta.

Mulgan, G. (2019). Social Innovation: How societies find the power to change. Policy Press.

OECD (2020). OECD Economic Outlook, No.107 (Edition 2020/1), OECD Economic Outlook: Statistics and Projection (Database), https://oecd.github.io/EOOutlook_chart_2/.

Office for National Statistics (2020). "Deaths involving COVID-19 by local area and socioeconomic deprivation: deaths occurring between 1 March and 17 April 2020”, ONS Statistical Bulletin

O'Hara, M. (2015). Austerity bites: A journey to the sharp end of cuts in the UK. Policy Press. 
Pol, E., \& Ville, S. (2009). Social innovation: Buzz word or enduring term?. The Journal of socio-economics, 38(6), 878-885.

Public Health Scotland (2020). What explains the spatial variation in COVID-19 mortality across Scotland? Available at:

https://www.publichealthscotland.scot/media/2814/spatial-variation-in-covid-19mortality-in-scotland-english-september2020.pdf

Ridley-Duff, R., and Bull, M., (2011). Understanding social enterprise: theory and practice, London: Sage

Social Enterprise UK (2011). Annual Review. https://www.socialenterprise.org.uk/seukimpact-reports-annual-reviews/annual-review-2011/

Spear, R., Defourny, J., \& Laville, J. L. (Eds.). (2018). Tackling social exclusion in Europe: The contribution of the social economy. Routledge.

Srnicek, N. (2017). Platform capitalism. John Wiley \& Sons.

Sumner, A, Hoy, C, Ortiz-Juarez, E (2020). Estimates of the impact of COVID-19 on global poverty. UNU-WIDER working paper, 2020/53. Available at:

https://www.wider.unu.edu/sites/default/files/Publications/Working-paper/PDF/wp202043.pdf

Teasdale, S., Alcock, P., and Smith, G., (2012). Legislating for the Big Society? The case of the public services (social value) bill. Public money \& management, 32 (3), 201-208.

van Barneveld, K., Quinlan, M., Kriesler, P., Junor, A., Baum, F., Chowdhury, A., Junankar, P.N., Clibborn, S., Flanagan, F., Wright, C.F. and Friel, S., (2020). The COVID-19 pandemic: Lessons on building more equal and sustainable societies. The Economic and Labour Relations Review, 31(2), 133-157.

Wiggan, J. (2017). Contesting the austerity and "welfare reform” narrative of the UK Government. International Journal of Sociology and Social Policy.

Williams, A., Goodwin, M., \& Cloke, P. (2014). Neoliberalism, big society, and progressive localism. Environment and Planning A, 46(12), 2798-2815.

Willis, R., Webb, M., and Wilsdon, J., (2007). The disrupters: lessons for low-carbon innovation from the new wave of environmental pioneers. London: NESTA. 